\title{
Are Demilunes in Mixed Salivary Glands Real or Fixation Artifacts? A Critique
}

\section{Bernard Tandler*}

Department of Biological Sciences, School of Dental Medicine, Case Western Reserve University, Cleveland, Ohio, USA

\begin{abstract}
Demilunes have historically been considered to be integral components of the secretory tree of mixed salivary glands. Based on preservation of rat sublingual glands by rapid freezing and freeze-substitution fixation, Yamashina et al. have advanced the notion that serous demilunes are artifactual products of chemical fixation, that swollen mucous cells cause a relocation of serous cells to the endpiece periphery. This concept has been uncritically accepted by several authors of histology textbooks. This note presents a compendium of observations and unanswered questions that render this proposition untenable.
\end{abstract}

\section{Keywords: Demilunes; Salivary glands; Fixation; Artifacts}

Mammalian salivary glands are a mélange of secretory units that consist of secretory cells and anastomosing ducts that ultimately debouch into the oral chamber. Using the direction of salivary flow as a convenient marker, the fountainheads of saliva production are the endpieces, which can assume various forms ranging from acini to elongated tubules. The secretory cells that make up these endpieces (the preferred term) can be serous, mucous, or seromucous in nature. In so-called mixed glands, the endpieces can consist of any two of these cell types, in any arrangement [1]. In such glands, the usual pairing of secretory cell types is that the closed terminal of the endpiece is capped by a second type of secretory cell, the demilune. To most histologists, the endpiece:demilune connection is best exemplified in the human submandibular and sublingual salivary glands, where mucous endpieces are capped by serous demilunes.

Discovered in 1865 by Giannuzzi [2], the relationship between endpieces and demilunes has been accepted as standard since its original description [3]. Recently, this structural pairing has been questioned by Yamashina et al. $[4,5]$. These authors claim that serous demilunes are an artificial byproduct of chemical fixation and that this rearrangement is prevented in rat sublingual glands by fixation by quick freezing followed by freeze-substitution. Despite the fact that this dubious proposition is riddled with errors of omission and interpretation, it has gained some currency and has uncritically appeared in several histology texts as established fact [6-8].This note is meant as a corrective to the false interpretation of demilune structure engendered by a flawed study.

In a nutshell, Yamashina et al. [4,5] claim that demilunes are formed by the expansion of mucous cells during chemical fixation. This conceivably could be the case where fixation is inadequate, as indicated by grossly swollen mucous granules with broken limiting membranes, but there are many instances in the literature where wellfixed, structurally-intact mucous tubules are capped by either serous or seromucous demilunes.

The following is a compendium of previously reported observations as well as questions that undermine the conclusion arrived at by Yamashina et al [4,5]. In the cat [9] and human [10] sublingual glands, some mucous secretory tubules are capped by serous demilunes, but for most or some of their length serous and mucous cell exist side by side with equal access to the lumen; serous cells have not been displaced towards the basement membrane. In the mastiff bat, serous endpieces are capped by a second type of serous cell [11]. Clearly, such serous demilunes are not formed by bad fixation of mucous cells, since there are no mucous cells whatsoever in these endpieces. A more telling example is provided by the submandibular gland of the European hedgehog [12]. In this gland, the endpieces consist of serous cells that are capped by mucous demilunes. If badly fixed mucous cells can reposition serous cells to a peripheral location, how did this latter configuration come about?

If, as Yamashina et al. [4,5] propose, serous cells are "squeezed out" from their original position in the endpiece by chemical fixation, how do the now confronted mucous cells form new junctional complexes? These are abundant in the rat sublingual gland that has been chemically fixed $[13,14]$. What happened to the original junctions between serous and mucous cells? Is there any evidence of disrupted tight junctions and desmosomes? How do microvillus-lined intercellular canaliculi form during the fixation process between artifactually adjacent mucous cells or between the apices of artefactual serous demilune cells and the bases of mucous cells? Such canaliculi, which are fitted with many microvilli, are separated from the intercellular space by junctional complexes for their entire length - where did the ostensibly new junctional complexes and microvilli come from? In many species, the basal surfaces of demilune cells are covered by interlocked basal folds-how do cells that according to the authors are being displaced during chemical fixation manage to become interlocked in so intricate a manner, especially since both desmosomes and gap junctions may be present on adjacent folds arising from different cells? In the developing rat parotid gland, there are conventional salivary mucous cells intermingled with serous endpiece cells [15]; when such fetal organs are chemically fixed, there are no demilunes-why not? Finally, Ichikawa and Ichikawa [16] illustrate serous demilunes in the sublingual gland of the gerbil despite the fact that their specimens were fixed by precisely the same fast-freezing, freeze-substitution method used by Yamashina et al. Why were demilunes present under these conditions? None of these significant questions are addressed by Yamashina et al. [4,5]

Although quick-freezing and freeze-substitution fixation

*Corresponding author: Bernard Tandler, School of Dental Medicine, Case Western Reserve University, Cleveland, Ohio 44106, USA, Tel: (216) 368-0563; Fax: (216) 368-6310; E-mail: bernard.tandler@case.edu

Received December 12, 2013; Accepted February 11, 2014; Published February 13,2014

Citation: Tandler B (2014) Are Demilunes in Mixed Salivary Glands Real or Fixation Artifacts? A Critique. J Cytol Histol 5: 218. doi:10.4172/2157-7099.1000218

Copyright: (c) Tandler B. This is an open-access article distributed under the terms of the Creative Commons Attribution License, which permits unrestricted use, distribution, and reproduction in any medium, provided the original author and source are credited. 
Citation: Tandler B (2014) Are Demilunes in Mixed Salivary Glands Real or Fixation Artifacts? A Critique. J Cytol Histol 5: 218. doi:10.4172/21577099.1000218

unquestionably produces better preservation of secretory granules, what is the evidence that cells as a whole are better fixed in this manner? In truth, the evidence is rather skimpy. In chemically-fixed mixed salivary glands where mucous granule preservation is very good (using the very criterion for judging good fixation employed by Yamashina et al. [4,5], namely, intactness of mucous granule membranes), serous demilunes still may be present. Even in those publications where preservation of mucous granules is not perfect, it is easy to judge that most of these structures have swelled to only a limited degree, certainly not to the point that they can produce massive relocation of serous or other types of adjacent cells. The only artifact that is readily observable in such cases is the displacement of the nucleus to the cell base-- in mucous cells that are well-preserved by chemical fixation, the nuclei maintain their central position in the cell, an indication that no meaningful swelling of the mucous granules has taken place; under such conditions, serous or seromucous demilunes still are present. Based on these sundry caveats, it is abundantly clear that demilunes are real, basic units of salivary gland structure.

To give Yamashina et al. [4,5] their due, their papers emphasize the fact that all cells in the endpiece make direct contact with the endpiece lumen. This point has long been a controversial one (see discussion by Tandler [17] and Pinkstaff [18]); ultrastructural studies now seem to indicate that bona fide demilune cells primarily empty their secretions into the intercellular canaliculi that make their way to the endpiece lumen, but that many of these cells also insinuate long extensions between endpiece cells to reach the lumen, providing a second pathway for secretions to be added to the initial saliva.

\section{References}

1. Heidenhain M (1920) NeueGrundlegungenzürMorphologie der Speicheldrüsen. AnatAnz 52: 305-331.

2. Giannuzzi G (1865) Von der Folgen des beschleunigtenBlutstromsfür die Absorderung des Speichel. BerkglsächsGesWis Math Physiol 17: 68-84.

3. Riva A, Testa Riva F (1998) Historical note: Giuseppe OronzoGiannuzzi and the discovery of the serous demilunes and of the intercellular canaliculi. Eur $\mathrm{J}$ Morphol 36: 15-18.

4. Yamashina S, Tamaki H, Katsumata O (1999) The serous demilune of rat sublingual gland is an artificial structure produced by conventional fixation. Arch HistolCytol 62: 347-354.

5. Yamashina S, Tamaki H, Katsumata O (2000) Review article fine structure of the exocrine cells of rat sublingual gland revealed by rapid freezing and freeze substitution method. Eur J Morphol 38: 213-218.

6. Ross MH, Pawlina W (2010) Histology. A Text and Atlas. (6thedn), Lippincott Williams \& Wilkins, Baltimore, USA.

7. Berkovitz BKB, Moxham BJ, Linden RWA, Sloan AJ (2010) Master Dentistry Volume 3 Oral Biology: Oral Anatomy, Histology, Physiology, Churchill Livingstone.

8. Eroschenko VP (2012) DiFiore's Atlas of Histology with Functional Correlations (12thedn), Lippincott Williams \& Wilkins, Baltimore, USA

9. Tandler B, Poulsen JH (1977) Ultrastructure of the cat sublingual gland. Anat Rec 187: 153-171.

10. Riva A, Tandler B, Testa Riva F (1988) Ultrastructural observations on human sublingual gland. Am J Anat 181: 385-392.

11. Tandler B (1993) Introduction to mammalian salivary glands. Microsc Res Tech 26: $1-4$.

12. Tandler B, MacCallum DK (1972) Ultrastructure and histochemistry of the submandibular gland of the European hedgehog, Erinaceous europaeus L. I. Acinar secretory cells. J Ultrastruct Res 39: 186-204.

13. Shimono M, Yamamura T, Fumagalli G (1980) Intercellular junctions in salivary glands: freeze-fracture and tracer studies of normal rat sublingual gland. $J$ Ultrastruct Res 72: 286-299.

14. Baker OJ (2010) Tight junctions in salivary epithelium. J Biomed Biotechno 2010: 278948

15. Ikeda R, Aiyama S (1997) Developmental changes in mucous cells of the early postnatal rat parotid gland: an ultrastructural and histochemical study. Arch HistolCytol 60: 185-193.

16. Ichikawa M, Ichikawa A (1987) The fine structure of sublingual gland acinar cells of the Mongolian gerbil, Merionesunguiculatus, processed by rapid freezing followed by freeze-substitution fixation. Cell Tissue Res 250: 305-314.

17. Tandler B (1993) Structure of mucous cells in salivary glands. Microsc Res Tech 26: 49-56.

18. Pinkstaff CA (1993) Serous, seromucous, and special serous cells in salivary glands. Microsc Res Tech 26: 21-31. 